\title{
Small Cell Variant Anaplastic Large Cell Lymphoma
}

National Cancer Institute

\section{Source}

National Cancer Institute. Small Cell Variant Anaplastic Large Cell Lymphoma. NCI

Thesaurus. Code C7208.

A histologic variant of anaplastic large cell lymphoma characterized by the presence of a predominant population of small to medium size malignant cells with irregular nuclei. 